www.jmscr.igmpublication.org

Impact Factor (SJIF): 6.379

Index Copernicus Value: 79.54

ISSN (e)-2347-176x ISSN (p) 2455-0450

crossrefDOI: https://dx.doi.org/10.18535/jmscr/v6i9.91

Journal Of Medical Science And Clinical Research

\title{
A review for Cryptosporidiosis among Immunocompromised Patients in Iraq
}

Authors

\section{Nadham K. Mahdi, M.Sc., Ph.D.}

Department of Microbiology, College of Medicine, University of Basrah, Basrah, Iraq

Corresponding Author

Prof. Nadham K. Mahdi

Central Post Office-42001, P. O. Box 1565, Ashar, Basrah, Iraq

Email: nadhammahdi@yahoo.com

\section{Abstract}

The prevalence of intestinal cryptosporidiosis among immunocompromised Iraqi patients including malignancy, receiving corticosteroid drugs, sicklers or protein-malnutrition is reviewed. The prevalence is also reviewed in relation to age and sex. Cryptosporidiosis is quite common in Iraq and it is considered as a public health problem among immunocompromised individuals. The combination between formalin-ether sedimentation plus modified cold Ziehl-Neelsen stain methods has been regarded with high sensitivity and specificity. The highest isolation rate for Cryptosporidium oocysts was observed during rainy winter season. Keywords: Cryptosporidiosis, Immunocompromised patients, Iraq, Sickle-cell anemia, Protein malnutrition.

\section{Introduction}

Cryptosporidiosis is an emerging zoonotic disease which leads to intestinal and extra-intestinal diseases in both humans and animals. The major factor controlling the susceptibility to and severity of cryptosporidiosis appears to be the immune status of the host ${ }^{(1)}$. Those with great risk of infection including the immunocomptomised patients $^{(2,3)}$. They are including AIDS patients and those with various malignant, cytotoxic drugs receivers, prolonged corticosteroid therapy, the drugs used to prevent organ transplant rejection ${ }^{(4)}$, those with chronic diseases and persons who have congenital immunodeficiencies ${ }^{(4,5)}$.

Cryptosporidiosis in those patients is characterized by debilitating, chronic, often cholera-like diarrhea associated with severe abdominal colic ${ }^{(6)}$, loss of more than $10 \%$ of body weight and dehydration ${ }^{(6)}$. Since Cryptosporidium is an opportunistic parasite, this review to determine the rate of cryptosporidiosis among immunocompromised patients including malignancy, receiving corticosteroid drugs, sicklersor protein-malnourished in Iraq.

\section{Results}

The prevalence of intestinal cryptosporidiosis is reviewed according to the types of immunosuppression.

Oocysts were found to be excreted is 5 out of 50 patients (10\%) with different malignant diseases during 1998 in Basrah, $\operatorname{Iraq}^{(7)}$ (Table 1). Most patients with cryptosporidiosis complain from abdominal cramping (90\%), water diarrhea (60\%) 
and weight loss (70\%). The associated symptoms were fever (40\%) and vomiting (30\%). The highest rate of infection was found $(20 \%)$ among children of $<6$ years of age. The male-female ratio was 2:3.

Cryptosporidium oocysts were found to be excreted by $10(9 \%)$ patients and $1(0.93 \%)$ of the control group (8) (Table 1). The highest rate of infection was noticed among patients with Hodgkin lymphoma (36.36\%). However, other rates of infection were ranged from $6.25 \%$ among patients with acute lymphocytic leukemia to $20 \%$ among patients with neuroblastoma ${ }^{(8)}$.

In Baghdad, Al-Warid et al., ${ }^{(9)}$ have discovered that the prevalence of cryptiosporidiosis was $76.66 \%$ among patients with lymphohematopoitic malignant diseases in comparison to $15.06 \%$ among healthy control group (Table 1). The highest rate was detected among patients with chronic lymphocytic leukemia (100\%) and multiple myeloma (100\%).

The only work which has been done in Basrah, Iraq and other Mediterranean region has recorded that $5 \%$ were found to be excreting Cryptosporidium oocysts among sickler patients (10) (Table 1).

In a case-control study, which involved 194 malnourished children below 5 years of age was done during $2001^{(11)}$. About $84 \%$ have marasmus, $8.24 \%$ marasmun-kwashiorkor, $6.18 \%$ kwashiorkor and $1.55 \%$ underweight. Cryptosporidiosis was found in $6.85 \%$ of children below 5 years with increased frequency among malnourished children with diarrhoea $14.89 \%$ compared to $11 \%$ in malnourished children without diarrhoea. Only $2 \%$ were noticed among well-nourished children with diarrhoea while no case has been recorded in well-nourished children without diarrhoea (Table $1)$.

Table 1 Prevalence of cryptosporidiosis among patients receiving corticosteroids or with malignant diseases or sickle disease or protein malnutrition

\begin{tabular}{|c|c|c|c|}
\hline Reference & $\begin{array}{c}\text { No. } \\
\text { Examined }\end{array}$ & $\begin{array}{c}\text { Characteristic for } \\
\text { population }\end{array}$ & $\begin{array}{c}\text { Prevalence } \\
(\%)\end{array}$ \\
\hline
\end{tabular}

I) $\quad$ Groups of people receiving corticosteriods

\begin{tabular}{|c|c|c|}
\hline \multirow{2}{*}{\multicolumn{3}{|c|}{$\begin{array}{l}\text { Ali \& Mahdi, } \\
\text { (7). } \\
\text { Infection was mainly found with } \\
\text { Blastocystishominis. }\end{array}$}} \\
\hline & & \\
\hline $\begin{array}{l}\text { Ali, } \\
\text { (18). }\end{array}$ & 60 & $\begin{array}{l}\text { Males \& females from Basrah } \\
\text { receiving corticosteroids. } \\
\text { Ages ranged }<6-65 \text { years. }\end{array}$ \\
\hline
\end{tabular}

Patients complain was abdominal cramp, watery diarrhea and weight Loss.

II) Groups of people with malignancy

\begin{tabular}{|c|c|c|c|}
\hline $\begin{array}{l}\text { Ali \& Mahdi, } \\
\text { (7). }\end{array}$ & 5 & $\begin{array}{l}\text { Males \& females from Basrah } \\
\text { with malignant disease. } \\
\text { Ages ranged } 16.5-55 \text { years. }\end{array}$ & 100 \\
\hline $\begin{array}{l}\text { Ali, } \\
(18) .\end{array}$ & 50 & $\begin{array}{l}\text { Males \& females from Southern } \\
\text { Iraq with malignant disease. } \\
\text { Ages ranged }<6-65 \text { years. }\end{array}$ & 8 \\
\hline $\begin{array}{l}\text { Al-Mkhtar\& } \\
\text { Al-Sherefat, } \\
\text { (19). }\end{array}$ & 107 & $\begin{array}{l}\text { Patients from Mosul (Northern Iraq) } \\
\text { with malignant disease during } \\
\text { 2002-2003. }\end{array}$ & 18.37 \\
\hline $\begin{array}{l}\text { Mahdi et al., } \\
\text { (8). } \\
<4-16 \text { years, Ir } \\
\text { to female ratio } \\
\end{array}$ & $\begin{array}{l}101 \\
\text { hern Ir } \\
: 1.0 . \mathrm{T}\end{array}$ & $\begin{array}{l}\text { Males \& females children with } \\
\text { malignant disease. Ages ranged } \\
\text { Iale }\end{array}$ & 9.9 \\
\hline
\end{tabular}


highest rate of infection $(36.3 \%)$

was observed in cases of

Hodgkin lymphoma.

\begin{tabular}{lll}
\hline Al-Waridet al., & 30 & Males \& females from \\
(9). & $\begin{array}{l}\text { Baghdad (Mid Iraq) with malignant } \\
\text { disease. Mean age 42.2 years. The }\end{array}$ & 76.7 \\
& &
\end{tabular}

highest rates $(100 \%)$ of infection were

Observedin chronic lymphoblastic leukemia

and multiple myeloma.

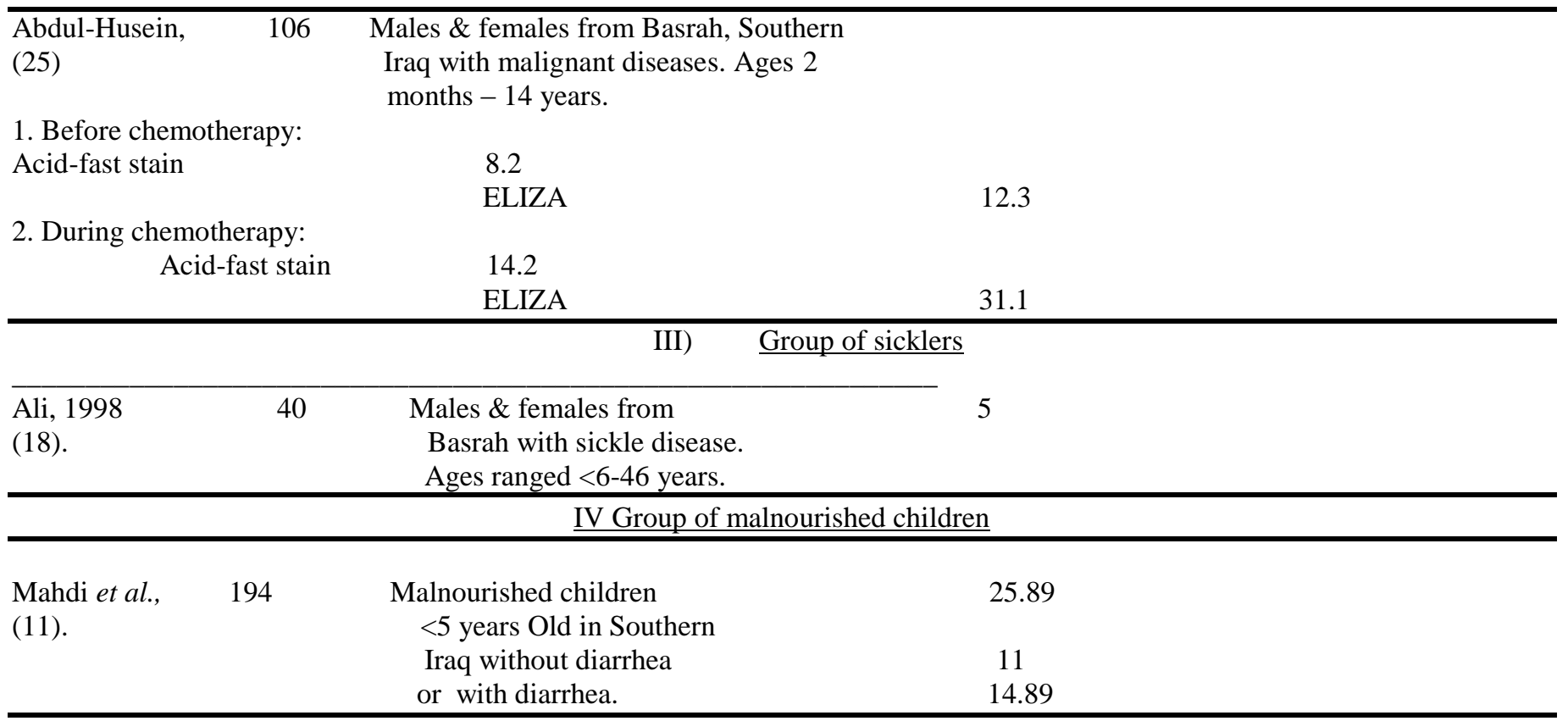

\section{Discussion}

The infection rate for cryptosporidiosis differ from one country to another and even from one area to another according to the sample size, diagnostic methods, availability of facilities and expertise. The source of infection was unknown ${ }^{(7)}$. None had direct contact with farm animals, nor contact with domestic pets. A zoonotic origin is possible with transmission via food, milk or water because their rural type of resident. Nosocomial mode of transmission may act as a possible additional rout in the studied patients.

It has been indicated that phagocytic activity, level of $\operatorname{IgM}, \operatorname{IgA}, \mathrm{IgG}$ and CD3, CD4 cells numbers were lower in patients than in control group while higher in case of C3, C4, CD8 and CD19 (8). The immunodeficiency can be caused by either the disease itself or the cytotoxic drugs or both of them.
The variation in the prevalence could be explained by the interaction with malnutrition ${ }^{(12)}$, chemotherapy ${ }^{(13)}$, other infections and animal contacts ${ }^{(14)}$. That would give a good indication for the relation of cryptosporidiosis and immunological status of the individuals just like opportunistic parasites.

Sickle cells anemia comprises a group of genetic diseases resulting from homozygosity of hemoglobin $\mathrm{S}(\mathrm{HbS})$, double heterozygosity of $\mathrm{HbS}$ and other abnormal hemaglobins and the presence of $\mathrm{HbS}$ in association with various types of thalassaemias ${ }^{(15)}$. It is relatively common in Iraq specially in the southern part. So, cryptosporidiosis among sicklers can be considered as the main cause of morbidity and mortality among those patients. The mechanisms contributing in the increased vulnerability to infection are splenic dysfunction, decreased IgM levels and defective alternative complement pathway $^{(16)}$. Some sickle cells cause blockage of 
the vessels supplying blood to an organ, leading to hypoxia of the organ and resultant cell death and progressive scarring. Also inadequate levels of $\mathrm{C}_{3} \mathrm{~b}$ lead to deficient opsonic activity and inefficient phagocytosis ${ }^{(17)}$.

Mahdi et al., ${ }^{(1)}$ have indicated that depressed cellular immunity characterised by decrease in total lymphocytes (particularly T-lymphocytes) was found among malnourished children either with or without diarrhoea. While humoral immunity (IgG, IgM, IgA) was significantly elevated among malnourished children with or without diarrhoea in comparison to well-nourished children. C3 and C4 were increased in malnourished children without diarrhoea with significant difference in $\mathrm{C} 4$ only. While they were decreased in malnourished children with diarrhoea, with significant difference in C3. In addition, Phagocytic activity showed a significant decrease in malnourished children with or without diarrhoea compared to well-nourished children ${ }^{(11)}$.

\section{Stool examination}

Even different methods were used but the combination between formalin-ether sedimentation plus modified cold Ziehl-Neelsen stain methods used by Ali \& Mahdi ${ }^{(7)}$ study have been regarded with high sensitivity and specificity due to oocyst concentration and differentiation them from other artifacts. In addition, this combination is cheap, rapid and easy to perform. That may give a strong suggestion to use this combination protocol as a routine diagnostic tool for patients with watery diarrheal symptom ${ }^{(18)}$. The prevalence would be higher if more than one stool sample from participants were examined due to intermittent shedding nature of the oocysts ${ }^{(6)}$. While Al-Mukhtar \& Al-Sherefat ${ }^{(19)}$ study reported that modified direct iodine stain method is the best technique for diagnosis of Cryptosporidium oocyst.

\section{Seasonal Variation}

The only report available is by Ali (18) in which he stated that the highest isolation rate for Cryptosporidium oocysts was observed during winter season, 1998 (24.44\%) similar to the seasonal pattern in Central America, India and Kuwait $^{(20,21)}$. In contrast, data from Massachusetts $^{(22)}$, Australia ${ }^{(23)}$ and Guatemala ${ }^{(24)}$ have noticed that the infection occurs in summer higher than in winter.

\section{Conclusions}

Cryptosporidiosis should be considered in differential diagnosis of undiagnosed chronic diarrhea in order to reach at the proper treatment. Management of complications, including infections, will reduce the suffering often faced by those patients and consequently improving the quality of life for them.

\section{References}

1. Current WL, Carcia LS. Cryptosporidiosis. ClinMicrobiol Rev 1991; 4: 325-358.

2. Fayer R, Vinger BL. Cryptosporidium sp. and cryptosporidiosis. Microbiol Rev 1986; 50: 458-483.

3. Hopelman IM. Human cryptosporidiosis. Int J STD AIDS 1996; 1: 28-33.

4. Markell EK, John DT, Krotoski WA. Markell and Voge Medical Parasitology. $8^{\text {th }}$ Ed. Philadelphia: WB Saunders Co, 1999: 389-398.

5. Spencer KC, Soave R, Acosta A. Cryptosporidiosis in HIV-infected persons: prevalence in New York population. Int $\mathbf{J}$ Infect Dis 1997; 1: 217-221.

6. Jokipii L, Jokipii AMM. Timing of symptoms and oocyst excretion in human cryptosporidiosis. The New Engl J Med 1986; 315(26): 1645-1646.

7. Ali NH, Mahdi NK. Cryptosporidiosis in patients undergoing immunosuppressive therapy. Tech Res J 2000; 12: 16-19.

8. Mahdi NK, Al-Sadoon MA, Hassan GK. Cryptosporidiosis and immunological status in children with malignant diseases. Med J BasrahUni 2007; 25(1): 1-6.

9. Al-Warid HS, Mahmood SH, Al-Saqur IM. Cryptosporidiosis among patient with 
and without lymphohematopoietic malignancy in Baghdad. Advances in Bioresearch 2012; 3(3): 38-41.

10. Mahdi NK, Ali NH. Intestinal parasites, including Cryptosporidium species, in Iraqi patients with sickle-cell anemia. Eastern Mediterranean Hlth J 2002; 8(2/3): 345349.

11. Mahdi NK, Hassan MK, Jassim RM. Intestinal parasitic infections including Cryptosporidiosis and immunological aspects among protein mal-nourished children. J Bahrain Med Soci 2005; 17(1): 43-48.

12. Paxton H, Cunningham-Rundles $\mathrm{S}$, O'Gorman MRG. Laboratory Evaluation of the Cellular Immune System. In: Henry JB. Clinical Diagnosis and Management by Laboratory Methods. $19^{\text {th }}$ Ed. Phildelphiaq, London: WB Saunders Co, 1996: 879-881.

13. Freifeld AG, Walsh TJ, Pizzo PA. Infection in the Cancer Patient. In: De Vita VT, Hellman S, Rosenberg SA (Eds). Cancer Principles and Practice of Oncology, Part 3, $5^{\text {th }}$ Ed. Phildelphia, New York: Lippincott-Raven, 1997: 2659-2661.

14. Rudrapantna JS, Kumar V, Sridhar H. Intestinal parasitic infections in patients with malignant diseases. J Diarrhea Dis Res 1997; 15(2): 71-74.

15. Warsy AS, El-Hazmi MAF. Bacterials infections and the sickling disorders. A review. Saudi Med J 1987; 8(3): 228-237.

16. Gavrilis P, Rothenberg SP, Guy R. Correlation of low serum IgM levels with absence of functional splenic tissue in sickle-cell disease. Am J Med 1974; 57: 242-245.

17. Onwabalili JK. Sickle-cell disease and infection. J Infec 1983; 7: 2-20.
18. Ali NH. Prevalence of cryptosporidiosis with zoonotic aspect. M.Sc. dissertation. University of Basrah, 1998.

19. Al-Mukhtar AM, Al-Sherefat NSS. Identification of Cryptosporidium among immunocompromised individuals. Ann College Med Mosul 2005; 31(2): 83-86.

20. Casemore DP, Wright SE, Coop RL. Cryptosporidiosis-human and animal epidemiology. In: Fayer R, editor. Cryptosporidium and cryptosporidiosis. New York: CRC Press; 1997.

21. Iqbal J, Hira PR, Al-Ali F, Philip R. Cryptosporidiosis in Kuwaiti children: seasonality and endemicity. ClinMicrobiol Infect 2001; 7(5): 261-266.

22. Wolfson JS, Righter JM, MacCathy D, Hopkins C. Cryptosporidiosis in immunocompetent patients. N Engl J Med 1985; 312(20): 1278-1281.

23. Tziporis S, Smith M, Birch C, Barnes G, Bristop R. Cryptosporidiosis in patients with gastroenteritis Am J Trop Med Hyg 1983; 32: 931-934.

24. Cruz JR, Cano F, Caceres P, Chew F, Parejia G. Infection and diarrhea caused by Cryptosporidium sp. among Guatemalan infants. J ClinMicrobiol 1988; 12(1): 8891.

25. Abdul-Hussein SM. Comporative study of diagnostic methods for cryptosporidiosis in children with cancer in Basrah. M.Sc. Thesis, College of Medicine, University of Basrah, Iraq. 